Cultures in Contact 
A book in the series

Comparative and International

Working-Class History

General Editors: Andrew Gordon, Harvard University

Daniel James, Indiana University

Alexander Keyssar, Harvard University 


\section{CULTURES IN}

\section{CONTACT}

World Migrations in the Second Millennium

\section{Dirk Hoerder}

Duke University Press Durham Æ London 2002 
(C) 2002 Duke University Press All rights reserved

First printing in paperback, 2OII

Printed in the United States of America on acid-free paper $\circledast$

Typeset in Trump Mediaeval by Tseng Information Systems, Inc.

Library of Congress Cataloging-in-Publication Data appear

on the last printed page of this book. 